\title{
RELATION BETWEEN AUTONOMIC NERVE SYMPTOMS AND FINGER VASOMOTOR REFLEX IN EPIPHARYNGITIS
}

\author{
By \\ SHIGEO HARADA \\ From the Department of Oto-Rhino-Laryngology, School of Medicine, Tokyo \\ Medical and Dental University (Director: Prof. S. Horiguti)
}

In order to explore a relationship between epipharyngitis and autonomic nerve function, the patients diagnosed as epipharyngitis from routine examination were observed for autonomic nerve symptoms and finger vasomotor reflex by the use of pneumatic strainguage plethysmography.

The results obtained are as follows:

1) There were discriminated two types of epipharyngitis; one with autonomic nerve symptoms which may be referred to as complicated epipharyngitis, and the other without autonomic nerve symptoms which may be called simple epipharyn- gitis.

2) The finger vasomolor reflex was found to be normal in the simple epipharyngitis, while in the case of the complex epipharyngitis it sho. wed a remarkable acceleration.

3) From the change of finger vasomotor reflex, epipharyngitis could be divided into four types as to its curing process.

4) Autonomic nerve symptoms and finger vasomotor reflex changed in parallel with the curing process of epipharyngitis.

\section{鼻咽腔炎に伴う自律神経症と指尖血管 運動反射との関倸について}

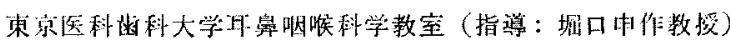

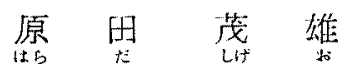

\section{目次}

\section{1 稀言业びに研究目的}

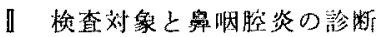

1. 㮝查刘承

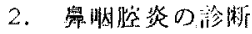

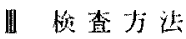

1. 症候学的自律科経機能壮態

2. Pneumatic strain gauge plethysmograph
(i) 装筧とその船部
(ii) 澌䇥方法と測定条件:

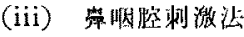

V 梌査成維

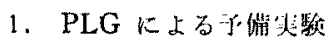

2. 鼻咽腔炎と指尖血管造倥反射

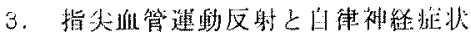

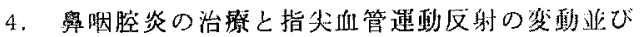
に日律神経拉状の消長

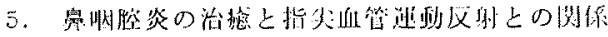

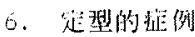

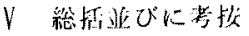

VI 衒 禁

\section{I. 緒言並Uに研究目的}

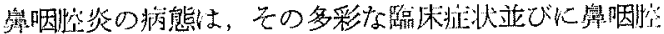

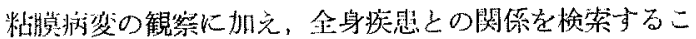

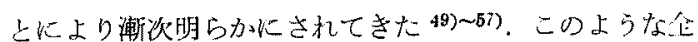

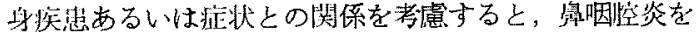

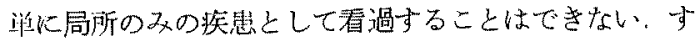
なわら，鼻㸶腔资の研究は全身各種臟器の生熊との関連 


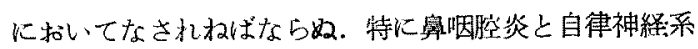
との関俰を解明することは最も重要な嘪であると考え られる、といらのは，生体調整機能の破綻を示すような

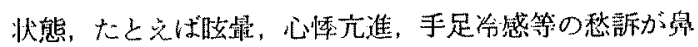

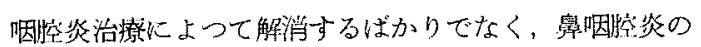

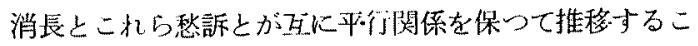
とが観祭されたがらである。

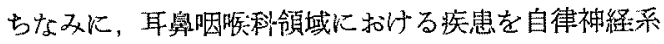
の面から追求することが近年とみに盛儿になつてきた。 そのらち奥咽腔炎と関係あるものを若下あげてみると：

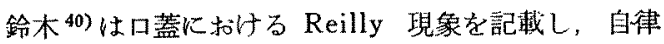
神経毒をモルモツトのロ蓋に注射してショツクを誘発す ると共に，脳波の思常や全身諸缄器に起つた伹管系由来

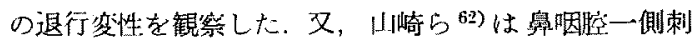

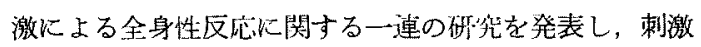

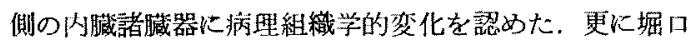

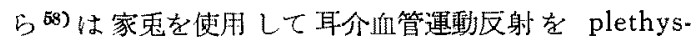
mograph に記録し，企身各所火種々の刺激を加えるこ

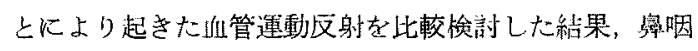
腔刺激が他の部位の刺激より強い反纫を示したと発表し ている。しかし，これら口墇ないし率㸶悾反射現象を臨 床面から観察した例は必ずしも多くない、敬室の田中4”

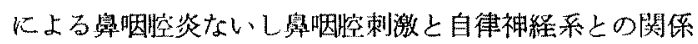
を体液学的立昜か、説いた䂺究等わずかをみるに過ぎな w.

以上概略的に述べたことからも舆咽腔が機能的に特殊 被刺激部位であることは明瞭であるが，奥咽腔がいかな る機構によつて自律神程不安定徽候々つながりを持つの か検索しなければならない、既知のよらに自律神経系は

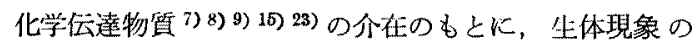
あらゆる場面亡密接な四係を有し，内分必，精神及び肉 体現象と複雑な相互関係を持つている，犹つて自律神絽

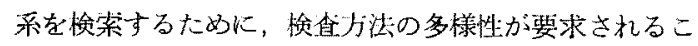
とは当然であるが，その1つとして坐体調整機能の破維

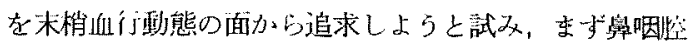
炎患者50名について, pneumatic strain gauge plethysmograph (以下 PLG と略記) を使州し指尖近管: 連動反射を測定してみた，その絬果，舀咽腔炎患者の指

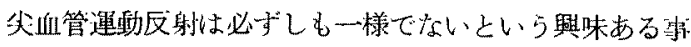

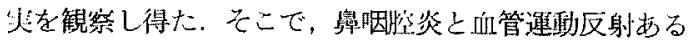
いは鼻咽腔炎に伴う自律神経掠状と血管運重反射とを刘 比させて観察したならば，舆咽娦の保持する特殊機構解 明の端緒を把握し得るかもしれないとの想定のもとに，

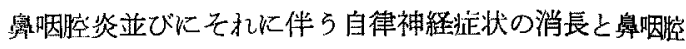
刺漖による指尖血管運動反射上の関係を検索し，多少の 所見を得たので報告する次第である。

\section{II. 検查対象と鼻咽炎の診断}

1. 検金刘象

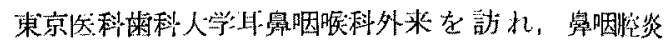
と紾断された患者 50 例で，自律神経拝状を誘発するよ らな原因を外に䛑めないるのを選んだ。性別は男子 15 例，女子 35 例で，年令分标は10才〜62才に及んでい 分。

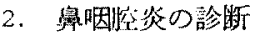

既に教室に执いて数次にわたり速べられているよら

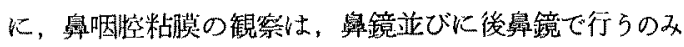
では不十分かつ不正確なために，鼻咽腔粘膜の直接察過 法による診断を基潐とした。すなわら村上 ${ }^{61)}$ ，井出 ${ }^{32) ， ~}$

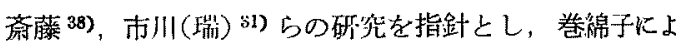

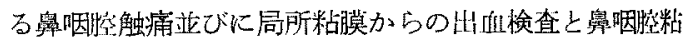

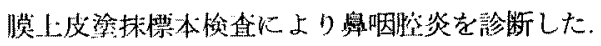

\section{III、自律神経系の検查方法}

\section{1. 怔候学的自律神絽练能状態}

鼠咽师空次と診䉼された患者が，果してどの程度に自律 神経定状を随伴しているか知る必要がある，第1表に

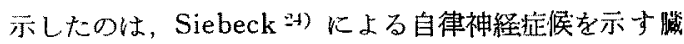
器拕状の分類上り，史際臨床上容易に检查可能な 10 症 状を選んだすのである。むちろん，一般的に自律神経挂 状として確認されているるのを選択した，又この分類が 全く正しいと考劣られない点も認めるが，そのまま引用 したことを付言して执く。これら10怔状の有無を決め るにあたつては閶彰及び諸娭査を参考にした。

第 1 表 自律神経症状 (Siebeck)

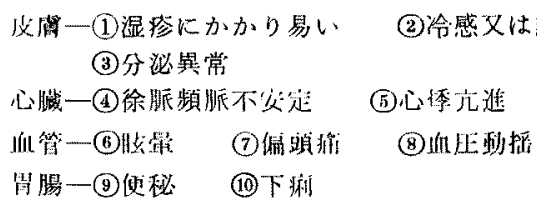

2. Pneumatic strain gauge plethysmograph 1905 年: Brodie 汭 は PLG の基礎的原理を碓立し，

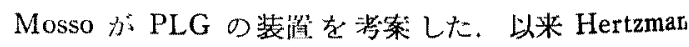

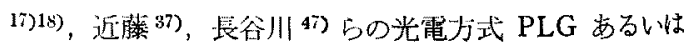
Getz ${ }^{1+)}$ の Hydro-PLG, Nyboer による Electrical impedance PLG など多種多様な PLG が考案された。 しかし签積変化の描記法としては Burch ${ }^{6)}$, Winsor ${ }^{28)}$ 
らの pneumatic PLG 及び Bachrach 1), 北 ${ }^{\text {36), }, ~ 山 ~}$ 口 ${ }^{64)}$ の strain gauge PLG がすぐれている。著者は 振幅変化と共汇容積変化を記録する目的で pneumatic strain gauge PLGを採用した.

（i）装置とその解説

実験に使用した pneumatic strain gauge PLG は 指炎 cup, strain gauge transducer, 增幅装置及び記 録装置から構成される. 以下その各々について 概説す る.

(1) Strain gauge transducer

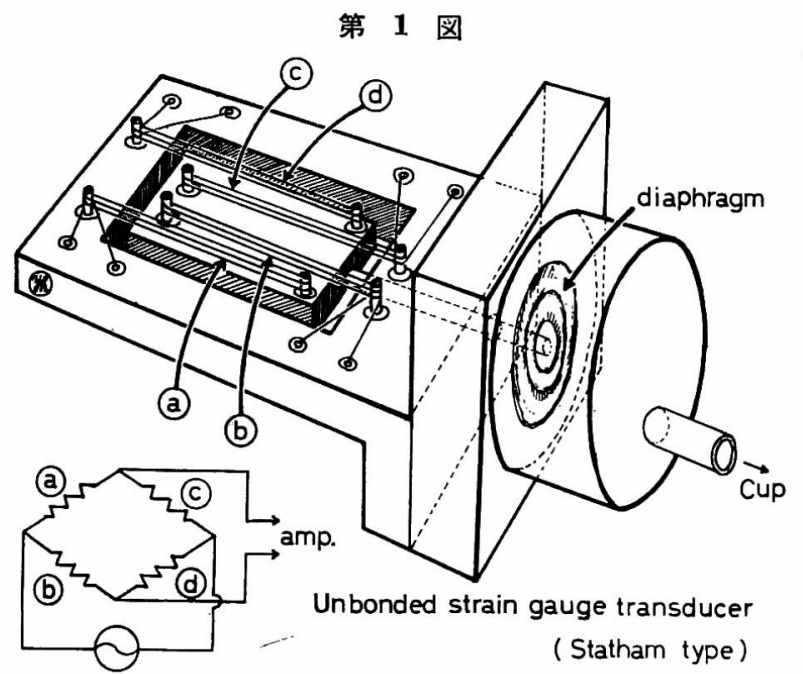

第 2 図

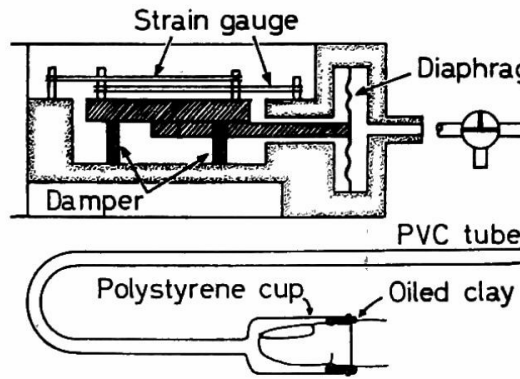

strain gauge transducer は原理的飞 Wheatstone bridge 回路に結合されている. digital cup から diaphragm そ陽圧が加えられた場合，内側の金属製抵抗 線 $\mathrm{b}$ 及び c は伸展し, 電気抵抗值が大きくなり, 外 側の金属製抵抗線 $\mathrm{a}$ 及ぶ $\mathrm{d}$ は弛緩して電気抵抗值を 小さくする.ここに, $\mathrm{d} / \mathrm{c}=\mathrm{b} / \mathrm{a}$ の関係で保持されてい
第 3 図 MFP-1 T圧力用 Trdnsducer

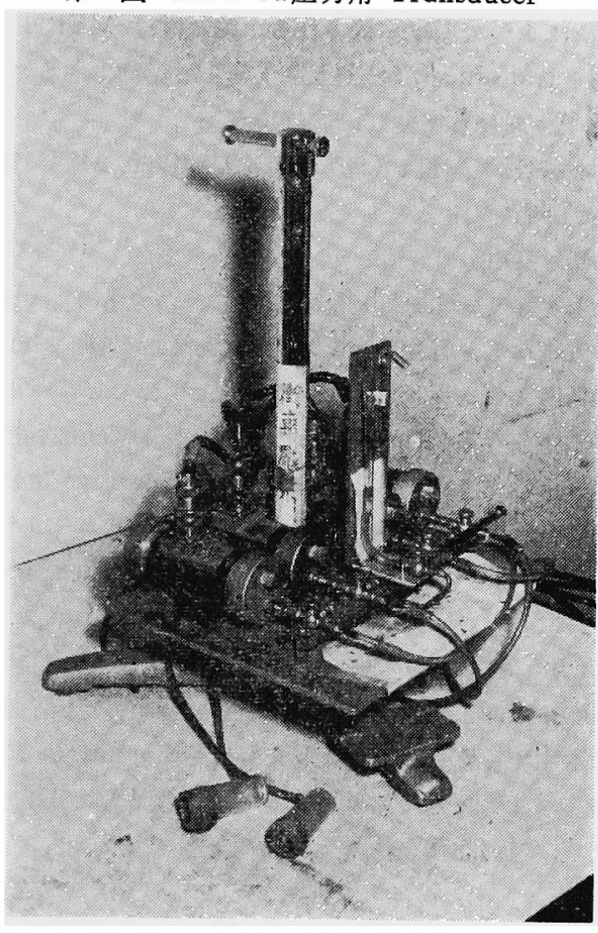

第 4 図 多用途記録装置 MFP 改良型

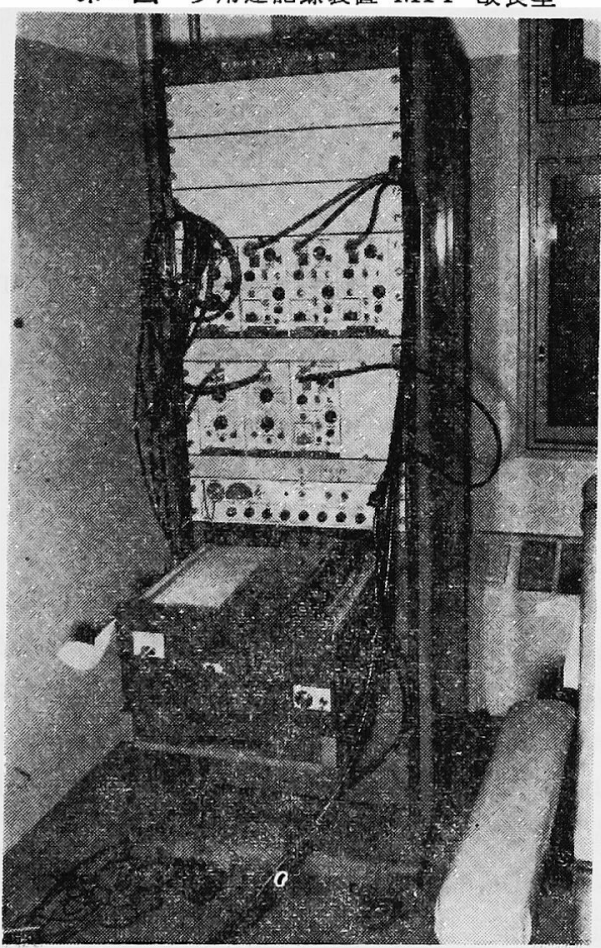


た平衡が破れ出力に变化を生じる，この出力变化が次の 装置によつて增幅記録される. 第3 図は MFP-1 T 压 力用 transducer (日光本電工業) の実物である.

（2）增幅装䁂並びに記録装置

堌幅及び記録には，多用途記録装置 MFP 改良型 （第4図）を用いた.

(3) Digital cup

本実験は指尖血行動態を钼察したので指尖 cup につ いて述べる. 容積 $14 \mathrm{cc}$, 内径 $20 \mathrm{~mm}$, 外径 $22 \mathrm{~mm}$ の 肉厚塩化ビニール cup を用いた。 このビニール cup 内に指を㨂入し oiled clay で固定, 插入指が完全に密 閉されるようにする. cup と transducer の間は, 内 径 $3 \mathrm{~mm}$ 前後, 肉厚 $1 \mathrm{~mm}$ 以上の塩化ビニール管で連 結する. 連結管は屈曲でき，乙かも拡張しないものでな ければいけない。

（4）原 理

cup 内插入部指尖の容積变化が空気圧を起し, 第 5 図 に示す如く塩化ビニール管を経て diaphragm に圧を 加光, この圧が strain gauge で電気回路の出力变化と なり，增幅回路を䌊て記録器に記録される。

\section{第 5 図}

装置のブロックダイアグラム

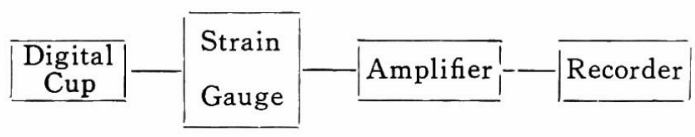

(5) Pneumatic strain gauge plethysmograph の 特性

strain gauge transducer の圧変化を增幅回路を経て pen-writing recorder に記録した場合，その response を manometer により水柱圧に換算できる，その特性 曲線は第 6 図のごときである。

(ii) 測定方法と測定条件

多用途記録装置の main switch を on にし，機械 が安定するまで待つ，少くとも30 分は必要である，機 械の安定後, 左右指尖 cup からの空気圧に対して, 各 々 strain gauge transducer が同程度の gain を示す ように, manometer を用いて転正する。次いで被検者 を第 7 図のごとく仰臥させ，指尖 cup を左右の第 3 指 に装着し鼻咽腙刺激により起きた指尖血管媈動反射を測 定した。
第 6 図

response $\rightarrow$ pressure 换算 曲線

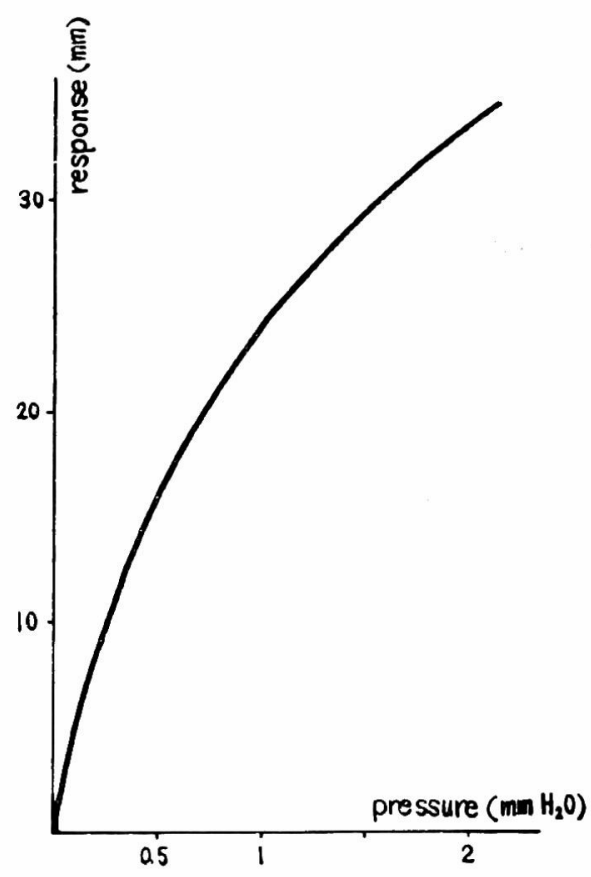

第 7 図 測定記錄中の全景

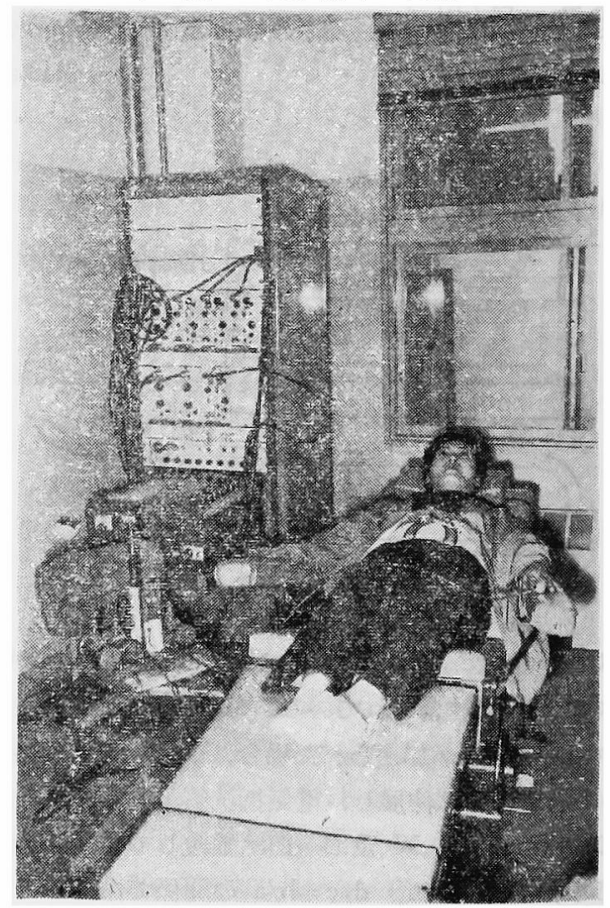


PLG を使用して末梢血行動態を钼察する場合，脈波 々形が内的，外的条件によつて，非常に影響を受け易い ことを充分考慮しなければならぬ．著者はこのことを留 意して，次の条件下で検査を行つた。

(1) 室温は $25^{\circ} \mathrm{C}$, 湿度 $65 \%$ の恒温恒湿にて実施し た. 検查は快適かつ恒常性の維持できる部屋でなされね ぱならぬ.

（2）被検者の体位は，可及的に安楽でなければいけ ない.この理由から腰部, 滕関節, 肘関節が適度に屈曲 できる椅子に仰臥させた．

（3） cup の位置は常に heart level にした.

（4）被検者の精神状態は Burch らのいらように, 眽波々型に非常な影響をもたらす。従つて被検者には検 查目的，簡単な機械の説明をし，検査に対する不安，恐 怖を除くようにした，そして，入室後少くとも30 分以 上安静を保たせた後施行した。

(iii) 鼻咽腔刺激法

前述したごとく，本実験は鼻咽腔刺激により起つた指 尖血管運動反射を観察したのであるから，簡単に刺激方 法を述べる. 刺激は鼻用巻綿子で経鼻的汇軟口蓋背面片 側汇 $1 \% \mathrm{Zn} \mathrm{Cl}_{2}$ 溶液を塗布した。 この場合, 被㭘者 が顔を歪めたり，軀幹四肢を動かさぬよう注意した。

\section{IV. 検查成績}

\section{PLG による予備実験}

\section{(i) 局所刺激による指尖血管運動反射}

実験的に血管運動反射を起す場合，その刺激には刺痛 刺激, 冷刺激, 温刺激, 深呼吸, 暗算等いろいろな種類 がある. 因8は自律神経症状を全く認めない成人に, 鼻 咽腔刺激, 刺痛刺激, 冷水滴下刺激を加えたときの指尖 血管運動反射を示す. 鼻咽腔刺激法については既に述べ た. 刺痛刺激は一側手背を注射針で軽く 1 回突いたもの である. 又, 一側手背に $10^{\circ} \mathrm{C}$ の冷水を 2,3 滴注射器 で落したのが冷水滴下刺激である. 刺痛刺激並びに冷水 滴下の場合, 刺激後直ちに基線の下降と共に振幅の縮小 をきたし，基線，振幅共に約 10 秒で刺激前の状態に復 している. 一方鼻咽腔刺激の場合, 基線, 振幅の回復時 間はやや長く，約 15 秒経過している. しかし，いずれ も同しょうな pattern を示している.

\section{基線及び振幅の意義}

このように末梢血行動態を plethysmogram（以下 PLGM と略記）に出現した基線及び 振幅の変化によつ て観察したのであるから，基線及び振幅変化の持つ意味 について考えてみたい.

\section{第 8 図 指尖血管運動反射（正常）}

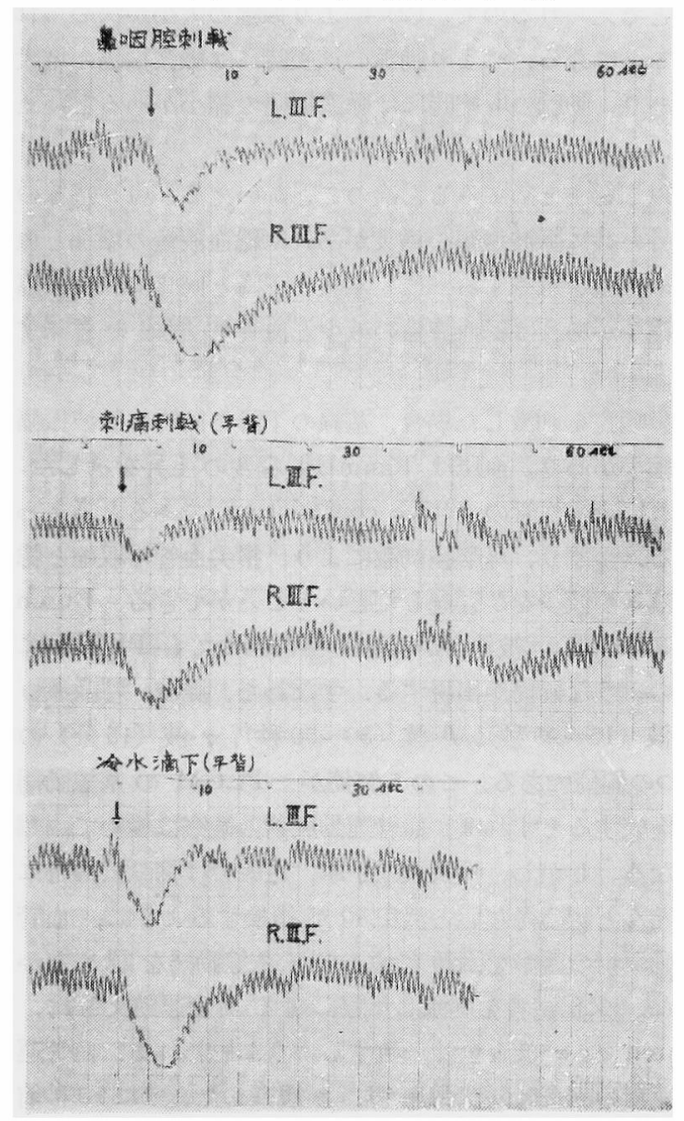

指尖 cup 内には, small artery. arteriole, capillary, venule, small vein, arterio venous shunt 等加 含まれる，乙か子指尖は筋肉を欠き，皮有，皮下組織， 骨よりなり，流出入血液，定常的血液，輸出入リンパ液， 定常的リンパ液及び組織液を含む．このうち容積変化の 主役を演じているのは，流出入血液及び定常的血液であ る. 従つて, cup 内血液量の变化は基線の上梨あるい は下降として記録される。しかし，基線の变動を観察し ただけでは末梢血行動態を充分に把握したとはいえな い，たとえば，静脈性うつ血の場合，基線が上戒しても 血流は減少しているのであるから， cup 内指尖の血量 增加を示すもので，血流の增加とはいえない，そこで， 基線の動摇と共に脈波振幅の变化を観察する必要が生じ てくる. Goetz によれば，挀波振幅は主として次の因 子に左右される。亦なわち，(1)一心搏動に上る搏山 量,（2）末梢血流の抵抗（動脈の vasomotor tone） 
（3）静脈性還流に左右される。このうち（1）（3）は一 定と考えられるので，（2）により振幅の大小が決められ ることになる。つまり動脈の搪張時には脈波振幅の增大 があり，動脈の収縮時には脈液振幅の縮小があるといえ る.

以上をまとめてみると次のことがい光る（1）基線の 上昇と共见脈波振幅の增大があれば総血液量の增加と血 管の脑張を意味する.（2）基線の下降と同時に脈波振幅 の縮小があれば総血液量の減少と血管の収縮を意味す る.

鼻咽腔を刺激した場合，基線の下降と同時に脈波振幅 の縮小があり，血圧は $10 \mathrm{mmHg}$ 程度の上昇を示した. これは末梢血管の active constriction であると考えら れる、つまり，鼻咽腔刺激により，指尖血管の収縮と総 血液量の減少をひき起したということができる，Burch 6)によれば，被検者が安静状態にあつても PLGM に 次のような偏倚が出現する。すすおち, 脈波, 呼吸波, $\alpha$ 波 (15 20 秒), $\beta$ 波 (30 50 秒), $\gamma$ 波 (15 分) の 5 つの偏倚である. この 5 偏倚が, PLGM の基線動摇 を構成するとすれば，血管運動反射の観察は極めて困難 となる。しかし，呼吸波は手掌，足蹠では仰卧安静時に ほとんど認め得ないと沢田 ${ }^{39)}$ が 指摘するように，血管 運動反射の観察を困難にするほど 基線動摇を認めなか つた. 又正常者を刺激した際に起る血管運動反射は, Burch の $\alpha$ 波と全く一致するように思われる．血管運 動反射の回復時間は長島 ${ }^{45)}$ ，が観察したように 10 秒前 後であり，年令により多少の延長，短縮を認めても，石 川 ${ }^{30)}$ が述べているよらに大人と子供あるいは男と女で 相違を余り認めない.

（ii）息こらえと指尖血管運動反射

鼻咽腔刺激は指尖あるいは趾尖を刺激するのと椲つ て，顔面に近寄らなけ机ばならぬ，この場合，被検者が区 射的に息をこら学るかもしれない，という疑問が当然子 想される。もしも鼻咽腔刺激に際し，被検者がいきこら えを無意識にしたと仮定すれば，PLGM に出現した変 化を，鼻咽腔刺激の結果と解釈することは誤りである. このような観点から，息こらえによる指尖血管運動反射 を，呼吸曲線を同時記録することによつて観察した．第 9 図に示すごとく，息こらえと同時に容積減少と振幅縮 小か゚起り，息こらえ中絶により容積と振幅は漸次回復す る.この回復時間は鼻咽腔刺激時のそれと比較すると， 遭かに長いことが了解される。 しかも, 興咽腔刺激によ る血管運動反射と同時記録した呼吸曲線には，ほとんど

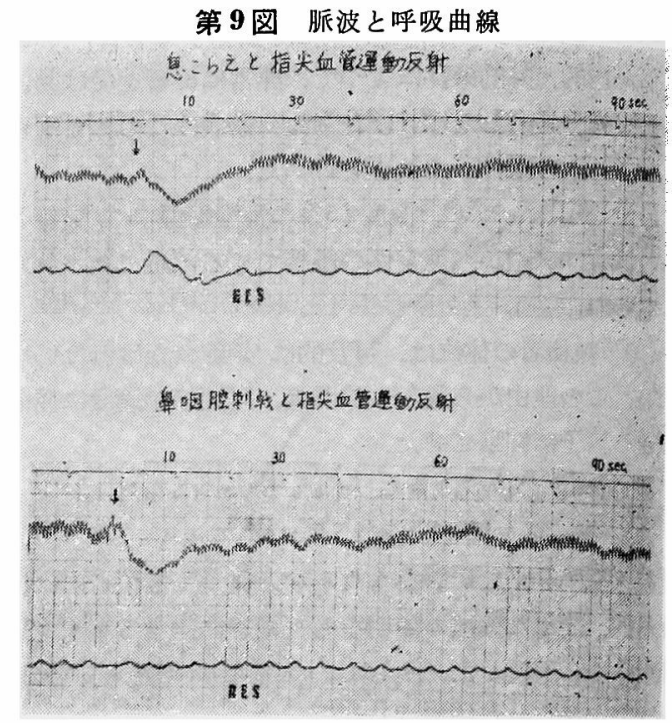

乱れを認めていない，従つて鼻咽腔刺激恃に，息こら兄 反射が加重されないことが分つた。

(iii) 標準值の決定

健康者 20 名の鼻咽腔刺激による 指尖血管運動反射の 测定值は第 2 表のごとくである．最高 30 秒，最低 10 秒 であり，平均値は16 秒，危険率 $1 \%$ の值は 25.37 秒で ある.よつて 30 秒以下を本実験の標準値とした。

\section{第 2 表 健康者の鼻咽腔刺激による指尖血管} 運動反射測定

\begin{tabular}{c|rr}
\hline $\begin{array}{c}\text { 振 幅 縮小 } \\
\text { 持 続 時 間 }\end{array}$ & 症 例 数 \\
\hline 10 秒 & 4 & 人 \\
15 & 10 & \\
20 & 5 \\
30 & 1
\end{tabular}

以上の予䚚実験により Burch らが確認した基線動摇 を構成する諸波も，血管運動反射観察の障害にならぬこ とが分つた，もちろん，基線を安定させるには検査室の 室温, 被検者に与える精神的影響, 被検者の服装, cup の位置等に充分注意しなければならぬ．又，鼻咽腔刺激 により起る健康者の指尖血管運動反射は，30 秒以下で 回復するのを確認した。

\section{2. 嶴咽腔炎と血管運動反射}

與咽腔炎患者について初診時に前記の方法により鼻咽 腔刺激を行い，指尖血管運動反射を測定したところ，そ 
の多数に反射が異常に克進（反応時間の延長）するのを みた. 血管運動反射と年令, 性別との関係は第 3 表のご とくである. まず振幅縮小回復時間が 30 秒以下の例, すなわち正常血管運動反射群をみると, 年令, 性別関 係なく平均して認められることが分る，これは正常血管 運動反射が年令，性別で著明な差のないことを証してい るむのと考兄られる. ただし PLGM の基線動摇は年 少者に比し年長者の方が安定していた，更に，振幅縮小 回復時間が 30 秒以上を示 したものを 血管運動反射異常 克進例とすれば，異常光進群は 30 秒〜300 秒以上に及 ぶ広範なばらつきを示しているが，60 秒以上の亢進例 が多数を占めていたので判定は容易であつた．この血管 運動反射異常光進群について, 性別, 年令との関係を㭘 討すると女子が圧倒的に多く，年令は 20 才〜 40 才の間 飞血管運動反射の異常六進者を多数みる。この結果, 鼻 咽腔炎患者のうち青年期，中年期の女子に血管運動反射 の異常六進を認めることが多いと考觉られるが，限られ

第 3 表 指尖血管運動反射と年令及び性別 (初診時)

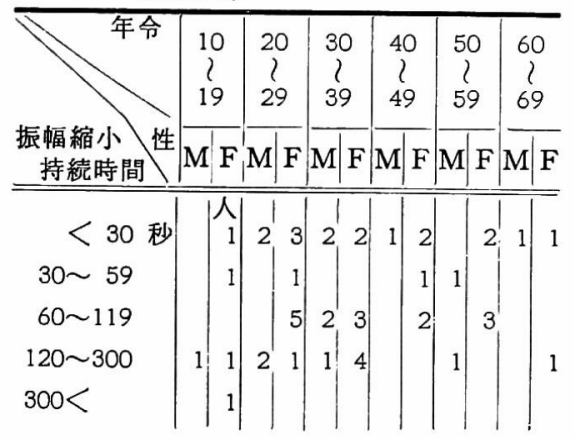

た症例数の観察によるので明確なことはいえない，とも かく，指尖血管運動反射を測定することにより，鼻咽腔 炎患者を 2 分し得ることが分つた。

3. 指尖血管連動反射々自律神経店状

前述したごとく，鼻咽腔炎患者は指尖血管運動反射の 誘発実験により, 正常血管運動反射を示すものと異常え 進反射を示すものとに分けられた。この両者間の相違を 随伴自律神経症状の面から探ぐり，同時に自律神経症状 と指尖血管運動反射との関係を検討してみた.

鼻咽腔炎患者 50 例の初診時に打ける 自律神経症状陽 性数と指尖血管運動反射との関係は第 4 表に示すごとく である. 表の自律神経症状陽性数は，第 1 表に記した 10 症状，1〜10 までの番号に関係なく陽性であつた数を表 わしている.これによれば血管運動反射の回復時間 30 秒以下の場合, 自律神経症状陽性数は1〜3であり, 回 復時間が 30 移以上に延長している場合には，症状陽性 数が 3〜 7である.すなわち, 鼻咽腔炎に随伴している

第 4 表 自律神経症状と指尖血管運動反射 (初診時)

\begin{tabular}{|c|c|c|c|c|c|c|c|c|c|}
\hline 自律神経症状 & \begin{tabular}{|l} 
症 \\
状 \\
陽 \\
性
\end{tabular} & \begin{tabular}{|l} 
症 \\
状 \\
陽 \\
性
\end{tabular} & 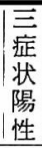 & \begin{tabular}{|l|} 
回 \\
症 \\
陽 \\
性 \\
\end{tabular} & \begin{tabular}{|l|} 
吾 \\
症 \\
陽 \\
性
\end{tabular} & $\begin{array}{l}\text { 咅 } \\
\text { 症 } \\
\text { 状 } \\
\text { 陽 } \\
\text { 性 }\end{array}$ & \begin{tabular}{|l} 
\\
症 \\
状 \\
陽 \\
性
\end{tabular} & \begin{tabular}{|l|} 
症 \\
状 \\
陽 \\
性
\end{tabular} & 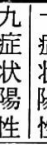 \\
\hline$<30$ 秒 & 人 & 7 & 3 & & & & & & \\
\hline $30 \sim 59$ & 1 & 1 & & 2 & & & & & \\
\hline $60 \sim 119$ & & & 2 & 7 & 4 & 1 & 1 & & \\
\hline $120 \sim 300$ & & & 2 & 2 & 3 & 2 & 2 & 1 & \\
\hline $300<$ & & & & & 1 & & 1 & & \\
\hline
\end{tabular}

第 10 図 a 自律神経安定型と不安定型の指尖血管運動反射

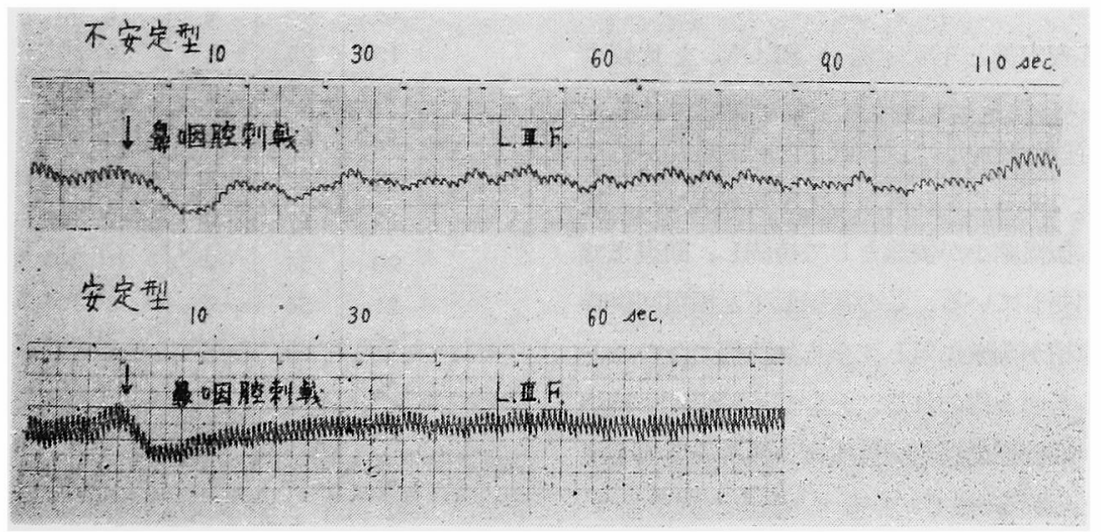


第 10 图 b 自律神経安定型已不安定型の指尖血管

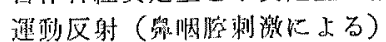

不家定垚

10

20

30 sec.

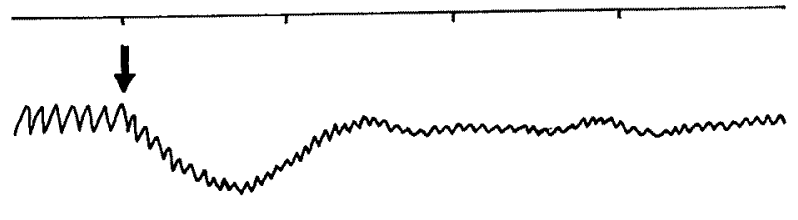

突定 晋

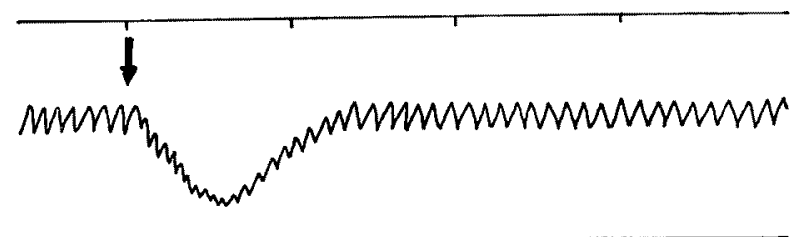

自律神経症状が少いと血管運動反射は正常であり，自律 神経症状が多いと血管運動反射も異常であることが明ら がなつた。このうち判定因難なのは，血管運動反射 30 秒以下で 3 症状陽性の3 例と反射が $30 \sim 59$ 秒で一症 状陽性ないし二症状陽性の 2 例上の計 5 例 (10\%) であ る.しかし自律神絽系の複雑性を考慮すれぱ，この上ら な例が出現するのも当然と思われる．以上，若干の例外 を認めても比較的少数であり，鼻咽腔炎は自律神释不安

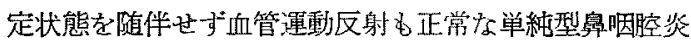
(仮称) と，自期神経不安定状態を有し血管連動反射の 異常充進を認める自律神経不安定型鼻咽腔炎（仮称）と に2大別し嶨た。

次に自律神経安定例と不安定例のP PLGM を比較す ると第10图 a.b. のごとくである．自律神経安定例で は，振幅樎小持続時間並びに基線低下の回復時間が短く 卧とえど同時性である，これに対して不安定例では，基 線が回復しても振幅縮小が依然として持䋹し，回復まで に比較的長時間要している，この基線低下と振幅回復時 間のずれは，末梢が刺激に対して全く無防備でないこと を暗示しているるのと思われる，ともかく振愊縮小持続 時間の延長は，血管連動反射調整機序の破綻を反映して いるるのと考えられる。

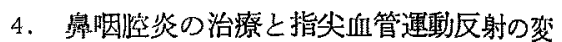
動並びに自律神経症状の消長

血管運動反射異常穴進例，すなわち自律神経 不安定型鼻咽腔炎患者に対して，1\% $\mathrm{Zn} \mathrm{Cl}$

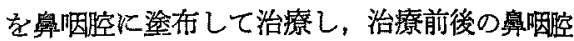
刺激による血管運動反射を比較観密した。その 25 例の結果は第 5 表に示すごとくである.

奥咽腔炎を治療することにより，治療前に認 められた指尖血管運動反射の異常卉進は，症例 $5 ， 12 ， 18 ， 22 の 4$ 例を除き，ことこととく正常化 されている，症例16のように振幅縮小持続時 間 30 秒の例む混在しているが，これらとて治 療前と比躈すれば，遥かに短緶して扣り，正常 血管運動反射に近い值である.

\begin{tabular}{|c|c|c|c|c|}
\hline \multirow{2}{*}{$\begin{array}{l}\text { 症 } \\
\text { 例 }\end{array}$} & \multirow{2}{*}{$\begin{array}{l}\text { 年 } \\
\text { 命 }\end{array}$} & \multirow{2}{*}{ 性 } & \multicolumn{2}{|c|}{ 桭幅樎小持続時間 } \\
\hline & & & 治 療 前 & 治竂媵 \\
\hline 1 & 26 & q & $4^{\prime} 00^{\prime \prime}$ & $15^{\prime \prime}$ \\
\hline 2 & 21 & 9 & $4^{\prime} \quad 40^{\prime \prime}$ & $15^{\prime \prime}$ \\
\hline 3 & 55 & 웅 & $1^{\prime} \infty 0^{\prime \prime}$ & $10^{\prime \prime}$ \\
\hline 4 & 33 & $\delta$ & $2^{\prime} 10^{\prime \prime}$ & $20^{\prime \prime}$ \\
\hline 5 & 29 & q & $50^{\prime \prime}$ & $55^{\prime \prime}$ \\
\hline 6 & 39 & 웅 & $1^{\prime} 00^{\prime \prime}$ & $10^{\prime \prime}$ \\
\hline 7 & 34 & 웅 & $2^{\prime} 40^{\prime \prime}$ & $10^{\prime \prime}$ \\
\hline 8 & 25 & q & $1^{\prime} 00^{\prime \prime}$ & $10^{\circ}$ \\
\hline 9 & 41 & 우 & $2^{\prime} 00^{\prime \prime}$ & $15^{\prime \prime}$ \\
\hline 10 & 21 & $q$ & $1^{\prime} 20^{\prime \prime}$ & $20^{\prime \prime}$ \\
\hline 11 & 26 & $\delta$ & $2^{\prime} 10^{\prime \prime}$ & $20^{\prime \prime}$ \\
\hline 12 & 13 & $\hat{\delta}$ & $3^{\prime} 20^{\prime \prime}$ & $2^{\prime} 10^{\prime \prime}$ \\
\hline 13 & 59 & $\hat{\delta}$ & $50^{\prime \prime}$ & $10^{\prime \prime}$ \\
\hline 14 & 43 & q & $1^{\prime} O 0^{\prime \prime}$ & $15^{\prime \prime}$ \\
\hline 15 & 25 & $\delta$ & $2^{\prime} 30^{\prime \prime}$ & $20^{\prime \prime}$ \\
\hline 16 & 21 & 우 & $1^{\prime} 30^{\prime \prime}$ & $30^{\prime \prime}$ \\
\hline 17 & 59 & $\delta$ & $2^{\prime} 40^{\prime \prime}$ & $20^{\prime \prime}$ \\
\hline 18 & 35 & $\hat{\delta}$ & $I^{\prime} 40^{\prime \prime}$ & $1^{\prime} 50^{\prime \prime}$ \\
\hline 19 & 17 & 우 & $2^{\prime} 10^{\prime \prime}$ & $20^{\prime \prime}$ \\
\hline 20 & 54 & 움 & $1^{\prime} 30^{\prime \prime}$ & $10^{\prime \prime}$ \\
\hline 21 & 56 & 8 & $1^{\prime} 10^{\prime \prime}$ & $15^{\prime \prime}$ \\
\hline 22 & 35 & q & $3^{\prime} 00^{\prime \prime}$ & $2^{\prime} 40^{\prime \prime}$ \\
\hline 23 & 50 & 우 & $I^{\prime} 10^{\prime \prime}$ & $15^{\prime \prime}$ \\
\hline 24 & 29 & $q$ & $3^{\prime} 20^{\prime \prime}$ & $15^{\prime \prime}$ \\
\hline 25 & 36 & 웅 & $I^{\prime} 40^{\prime \prime}$ & $20^{\prime \prime}$ \\
\hline
\end{tabular}


第 11 図治療前後における指尖组管運動反射の比較

指尖脈波（䋰咽腔刺戟と血管運動反射）

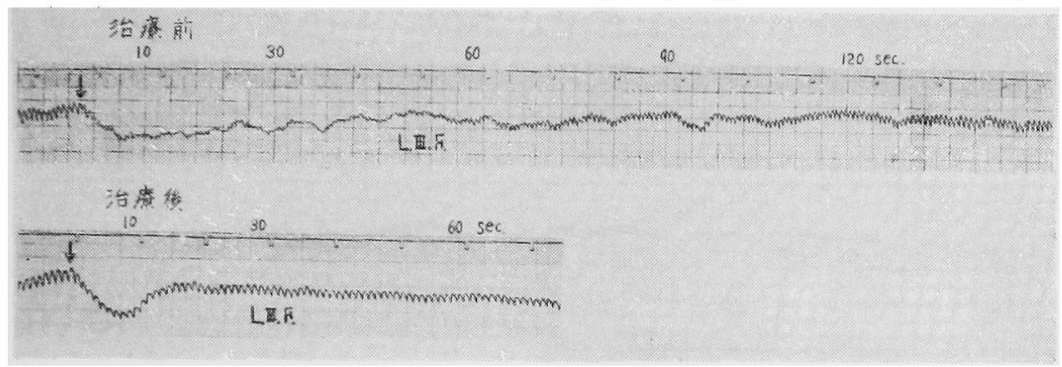

第 6 表 治療前後の自律神経症状の比較

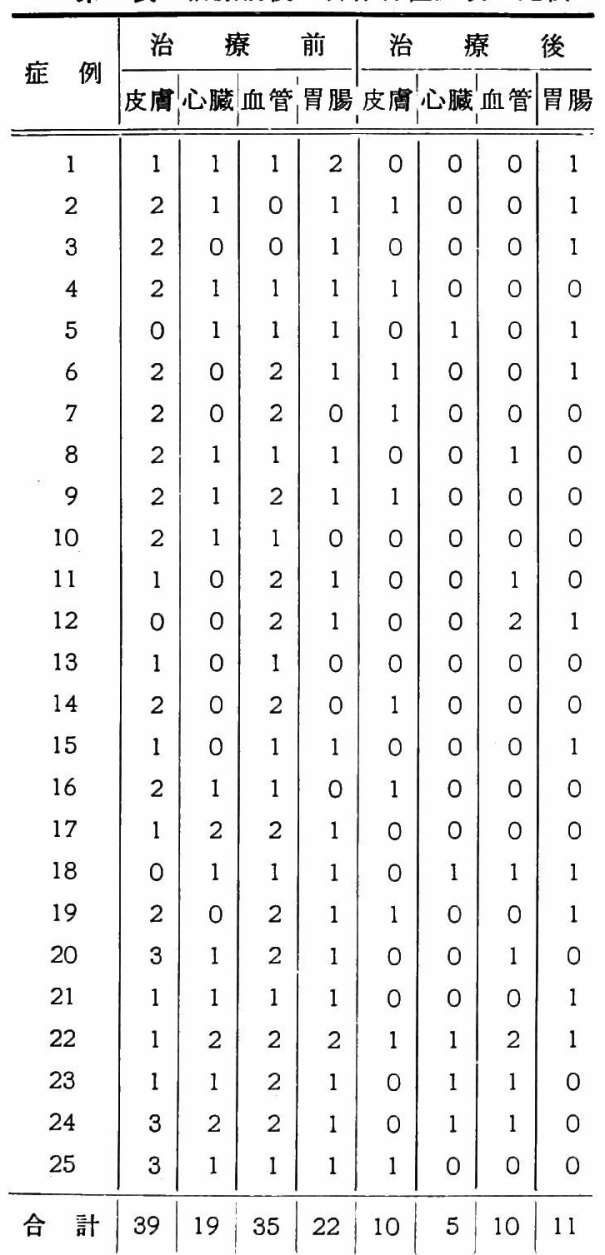

第 11 図は, 治療前後における血管運動反射の变動を 示した PLGM の1例である. 治療前後の血管運動 反射は，あたかも自律神経安定者と不安定者， 2 人の
PLGM を見るかのように差異のあることが観察され る. 治療前に比較し，治療後には，振幅縮小持続時間の 短縮のみか，基線の安定をも見ることができる.

一方，自律神経症状の鼻咽腔炎治療による消長はどう かというと第6表のごとくなる。

表にみられるように，25 例中症例 $5,12,18,22$ の 4 例を除いたほかは，いずれも治療前に比較し，治療後の 自律神経症状は軽減している。ここで注目に值するの は，自律神経症状の軽減をみない例，すなわち症例 5, 12，18，22 が，血管運動反射の正常化を得られなかつた 症例と全く一致していることである.

この事実は，自律神経不安定状態の鎮静と血管運動反 射の正常化とが，全く平行関係にあることを証明するも のである．ここで更に詳細に検討すれば，完全に鎮静し た例は比較的少く, 症例 $10,13,17$ の僅か 3 例をみるに すぎないが，大半の患者は遗残した自律神経症状を苦に してないことから，自律神経不安定状態から脱したとい うことができる．しかも，自律神経安定群でさえ，1な いし 2 症状陽性であるのが一般であることから，この程 度の遺残はむしろ当然な結果といえる。

ともあれ，鼻咽腔炎を治療することにより，指尖血管 運動反射の正常化と並んで自律神経不安定状態の鎮静々 が得られた. 従つて, 自律神経不安定状態の消長は, 血 管運動反射の変動を観察することにより間接的に察知し 得る.

第 12 図は鼻咽腔炎の治療により，指尖血管運動反射 の回復時間が漸次短縮していく過程を示したものであ る. 初診時には 4 分 40 秒も血管運動反射の 回復時間を 認めたのに, 鼻咽腔炎治療により 4 カ月後には全く正常 の血管運動反射になつているのが分る。 
第 12 図 治㾤過程と指尖脈波の变動

T.K. $21 \mathrm{~F}$ ※

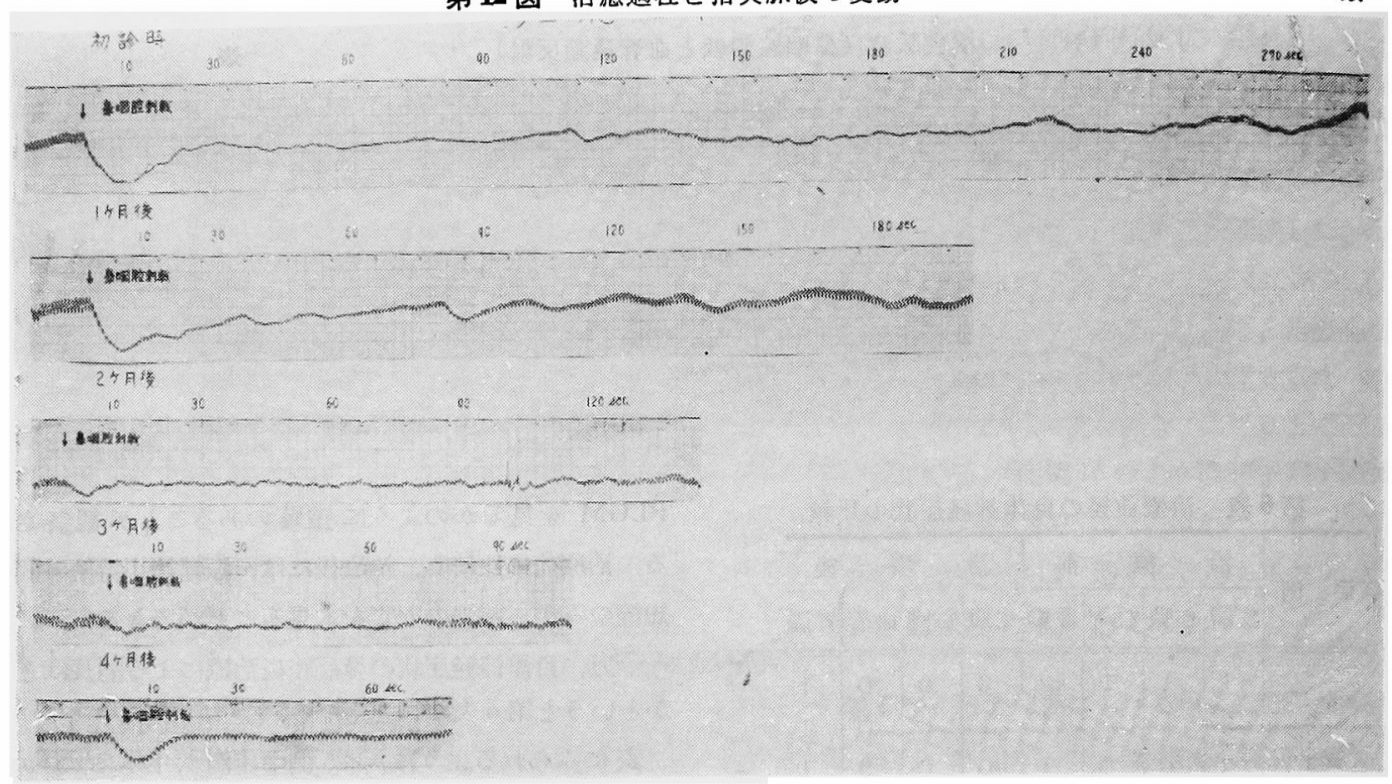

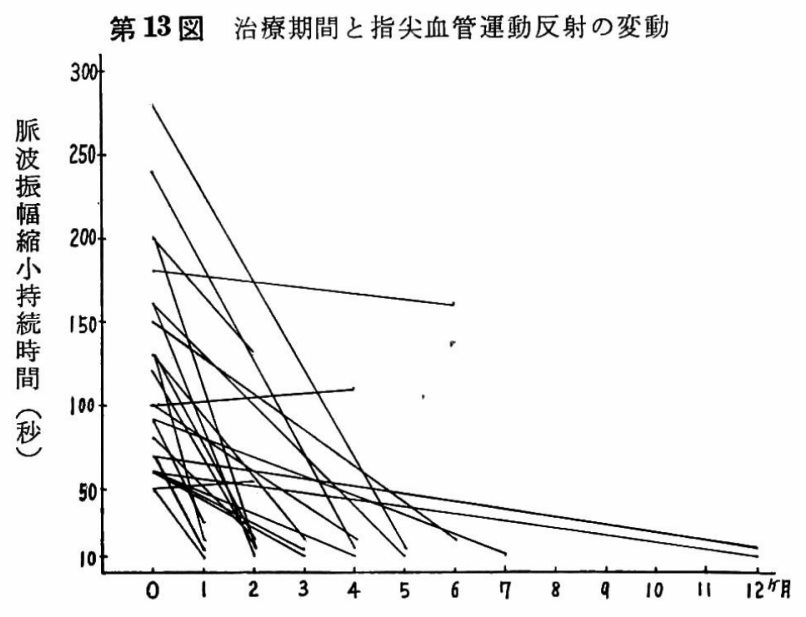

第 13 図は，治療期間を加 えて，治療前後の血管運動 反射の変動を示したものである.これによれば，㝴咽膑 炎の治療により正常血管運動反射を得るまでの期間が歴 然として観察できる. 大体，1ないし 2 カ月の比較的短 期間で正常血管運動反射を得る群と, 血管運動反射が正 常になるまで 3 カ月上要する群のあることが分る.し かも，正常血管運動反射に達するまで，つまり自律神経 不安定状態の鎮静をみるまで 12 力月といら長期間を要 した例を認める. 従つて, 自律神経不安定型鼻咽腔炎の
治療には相当の根気を必要とする場合がある。 血管運動反射の改善をみなかつた 4 例の中, 治 療後の血管運動反射が，治療前に比し逆に元進 している例のあることに注意を置きたい，この ように血管運動反射が充進する場合, 自律神経 不安定状態の鎮静を得ることが, 容易でないこ とを暗示しているものと考えられる。

5. 鼻咽腔炎の治療と指尖血管運動反射との 関係

治療前, 治療後の 2 時点に拈ける指尖血管運 動反射を比較するのみでは，鼻咽腔炎の治瘜過 程を充分に把握し得ない，よつて，血管運動反 射の変動より鼻咽腔炎治癒過程の分類を試み た。これによれば，鼻咽腔炎治療と血管運動反 射異常充進の正常化との関保は必ずしも単一で ない. 第 14 図は, 治癒 I 型, 治癒 I 型, 治癒凹型及び 非治瘉型の 4 型に分類されることを示するのである. 治 癒 I 型は比較的短期間で正常血管運動反射を得た例であ り, 治癒 I 型は血管運動反射の回復時間が治療月数と共 に潮減した例である. 更に治癒而型は，治療過程に捺い て血管運動反射の回復時間が短縮したり延長したり動摇 しながらも正常血管運動反射を得た例である.なお，【 型、而型の治癒にはかなり長期の治療を要した。 又非治 


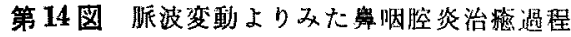
の分類

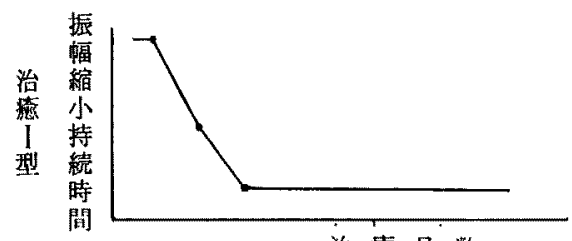

治療月数

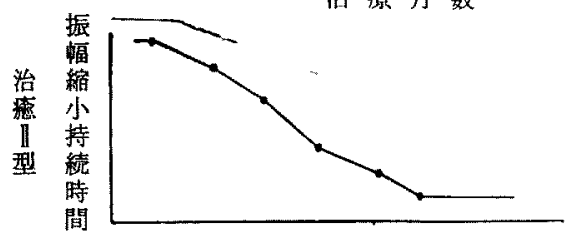

治療月数

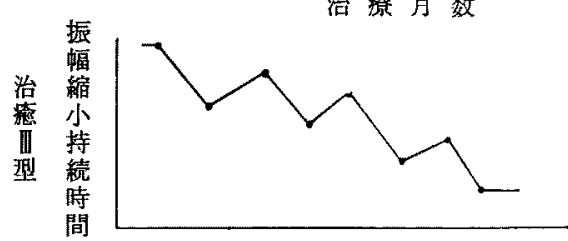

治療月数

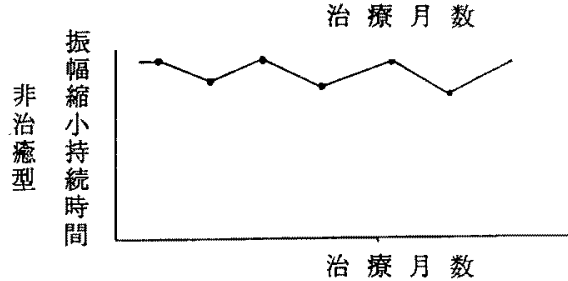

第 7表 脳波変動分類に上る治療成績

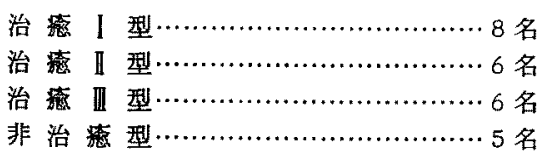

第 8 表 咽腔炎の治痖に要した期間

\begin{tabular}{l|l|l|l|l|l|l|l|l|l|l|l|l}
\hline 治療月数 & 1 & 2 & 3 & 4 & 5 & 6 & 7 & 8 & 9 & 10 & 11 & 12 \\
\hline \hline 症例数 & 3 & 5 & 3 & 3 & 2 & 1 & 1 & 0 & 0 & 0 & 0 & 2
\end{tabular}

疮型は，多少の变動を示しながらも，遂に正常血管運動 反射老得られなからた例をいら。これら各型の症例数

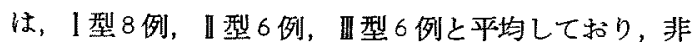
治忿型のみ 5 例と僅が少数であつた (第7表).

ここで, 各型と臓器別自律神経症状との関連性, たと えば心臟症状を主とするるのはどの型多いかといらこ とを検索したが，特別の関係を把握し得なからた。

既述したごとく，血管運動反射の変動と自律神経症状 の消長とは平行関係を保持して推移するのであるから， 初診時にみられる臟器別自律神経症状も第 14 四の曲線
に平行して推移して行くといまる。

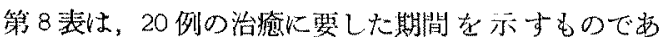
る. 表上り自律神経不安定型鼻咽腔炎は，1 カ月から4 カ月の間に治癒例の多いことが分る。な批観察範团内で の傾向を述べれば，局所の炎症が消退した後も自律神経 不安定状態の持続した例が多かつた。

\section{6. 定型的症例}

鼻咽腔桨並びに自律神絽不安定状態の消長と指尖血管 罢動反射の変動とを，経過を追つて観察し得た症例の5

ち，定型的なものを2 例紹介する。

症例! T.Y. 59 才， 古

初診日：昭和 39 年 12 月 21 日

主 訴: 後鼻漏, 左偏頭痛

診 断: 鼻咽腔炎

既往歷：特記すべきものなし

来院時までの繦過

昭和 39 年 9 月より後番漏, 舅閉感と共に左偏頭痛を 認めるようになる。昭和 39 年 10 月，某耳鼻科化て精密 検查を受けたが，異常ないといわれた。そその後放置した ままであつたが，1 カ月前より後鼻漏の活か炕心悸立 進，眩最をも認めるようになつた。な推胘量の種類は立 らくらみである.

初䇏時局所名見

鼻鏡並びに後鼻鏡検查にて楀咽院粘膜に軽度の発赤と 蛙液性分速物を認め，鼻用巻綿子にて軟口蓋背面を擦過 すると，高度 (H) の触痛を訴古, 高度 (HI) の出血を みた。

\section{初竞時検查}

\section{鼻咽腔上皮の剝離塗抹像}

線毛細胞は，ばらば吼いし塊状以多数出現し，ての 線毛構造, 小皮緑は比較的明瞭で, 細胞質の膨化は較度 である。その活か，杯状細胞の增加と多核白血球，リン ハ球などの遊走細胞が少数みられる。

自律神経症状 (Siebeck)

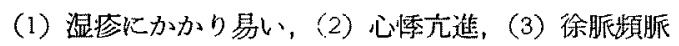
不安定，(4) 左偏頭痛，(5) 胘聂，(6) 便秘傾向の6 症 状陽性.

指尖脈波

脈波振幅縮小持続時間，160 秒

以上の結果から帠咽空炎の䛦溯並びに自律神絓不安定 状態を有することが確定し，局所治療を開始した．その 治療経過恃第 9 表及び第 15 図に示すごとくである， 
第 9 表 证例 | T.Y. 59. M

\begin{tabular}{|c|c|c|c|c|c|}
\hline \multirow{2}{*}{$\begin{array}{l}\text { 治 䤃 } \\
\text { 月数 }\end{array}$} & $\underline{1}$ & 律 & \multicolumn{2}{|c|}{ 経 症 状 } & \multirow{2}{*}{$\begin{array}{l}\text { 脈 波 } \\
\text { 振幅縮少 } \\
\text { 持続時間 }\end{array}$} \\
\hline & 皮盧 & 心 缄 & 血 管 & 胃 腸 & \\
\hline 0 & 湿 疮 & \begin{tabular}{|l} 
心震圥進 \\
安定
\end{tabular} & 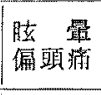 & 柲 & 160 秒 \\
\hline 1 & 湿疹 & & 编頭疬 & & 20 秒 \\
\hline 2 & 湿 疮 & 心悸充進 & 偏頭游 & & 60 秒 \\
\hline 3 & 湿 疹 & & & & 10 秒 \\
\hline 4 & & & & & 10 秒 \\
\hline 5 & & & & & 10 秒 \\
\hline
\end{tabular}

第 15 図 症例 T.Y. 59 万

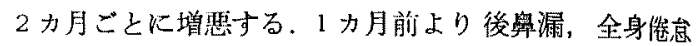
感のほかに, 全身冷感, 心悸亢進をも認める。

\section{初䛦時局所々見}

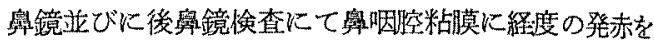

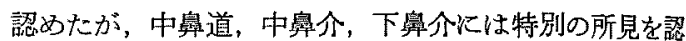
めなからた，鼻用並びに咽頭用巻綿子にて軟口蓋背面を

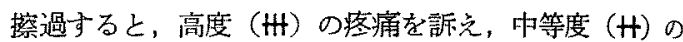
出血をみた。

\section{初診持検查}

粤咽腔上皮の剝離涂抹像

線毛細胞は、ばらばらに多数出現し，その線毛構造， 小皮縁は不明腺で，細胞質の膨化も高度であり，線毛の 脱落世る細胞も多い，そのほか，中等数の白血 球，リンパ球などの遊走細胞がみられ，ごく少 数の扁平細胞が混在している。

顔面レントゲン写真

異常所見なし

自律神経症状 (Siebeck)

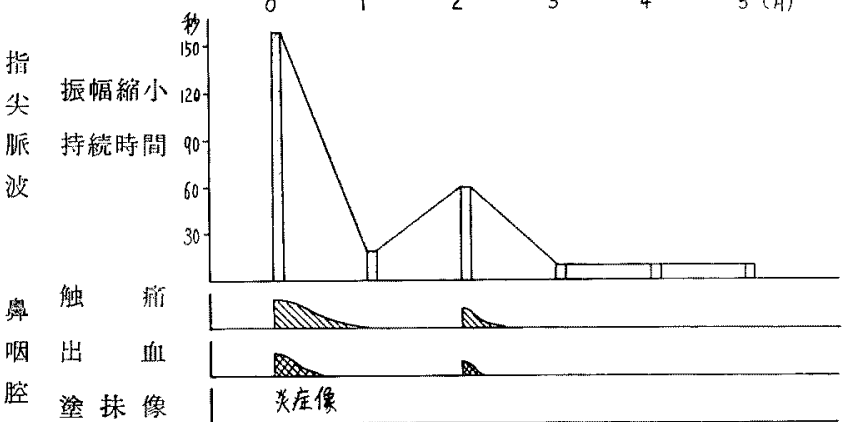

（1）手足冷感，（2）心悸穴進，（3）胘最，

（4）便秘，(5) 下痢の 5 症状晹性.

指尖脈波

振幅縮小持続時間 240 秒

以上の諸検查上り鼻咽腔炎並び沉自律神繦不 安定状態を有すことが確定し，奥咽腔炎治療を 施行した，治癒比至るまでの経過は第10表及 び第 16 図に示すと括りである。

治燎開始後6 週間，鼻咽腔触痛，出血忚消失

治療開始後 3 力月，鼻咽腔触痛並びに出血を認めなく なり，上皮崄莱像は線毛緇胞小数，小皮縁明膫，細胞質 の膨化消失し炎症所見至認めなくなる，ただ，自律神絽 症状のらち，皮鹰症状が依然として続いたが，治療4カ 月に心この症状当消失し，血管泻動反射む10秒となつ た。

症例』 R.K. 26 才， 古

初骖日：㗊和 38 年 11 月 21 日

主 訴：後䁷漏，全身隐意感

診䀿: 鼻咽腔炎

既往歴：特記す心゙きるのた

来院時末での経過

昭和 37 年夏, 感冒に羅患してから多量の鼻漏を認め るようになる。炤和 38 年 4 月上り某耳鼻科にて奥炎の 䛦断のもとに治療を受けるよらになつたが，その後も

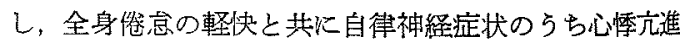
と眩星を認めなくなつた。この時の振幅縮小持続時間は 110 秒であり，初診特に比しやや短縮した，更に治䖍を

第 10 表 症例 \| R.K. 26. F.

\begin{tabular}{|c|c|c|c|c|c|c|c|c|c|}
\hline \multirow{2}{*}{$\begin{array}{c}\text { 治療月数 } \\
\text { (週) }\end{array}$} & \multicolumn{3}{|c|}{ 自 律 } & \multicolumn{2}{|c|}{ 神 経 } & \multicolumn{2}{|c|}{ 症 状 } & & \multirow{2}{*}{ 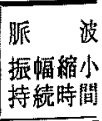 } \\
\hline & 皮 & 用 & 心 & 䁍 & 血 & 管 & 胃 & 腸 & \\
\hline 0 & 冷 & 感 & 心悸 & 穴進 & 眩 & 叠 & 便 & 秒 & 240 秒 \\
\hline 3 & & 感 & & & & & $\frac{\text { 便 }}{F}$ & $\begin{array}{l}\text { 秘 } \\
\text { 利 }\end{array}$ & 135 秒 \\
\hline 6 & & 感 & & & & & 更 & $\begin{array}{l}\text { 秘 } \\
\text { 㢉 }\end{array}$ & 110 \\
\hline y & & & & & & & 便 & 秘 & \\
\hline 12 & & & & & & & 便 & 秘 & 15 \\
\hline 0 & & & & & & & 便 & 秘 & 15 秒 \\
\hline
\end{tabular}




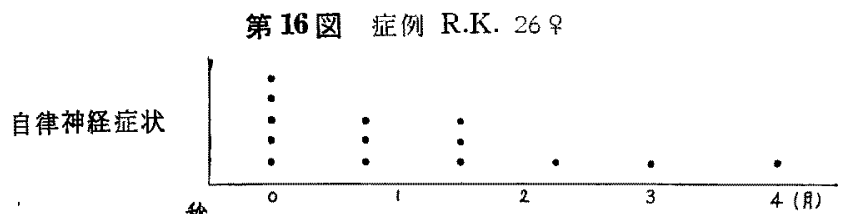

経の不安定状態を血管連軼反射の筫常光進とい う客観的な現象に上つて把握し得たといるる。 又，血管運動反射並びに随伴自律神経よりみ て，鼻咽腔炎を 2 大別することが可能である.

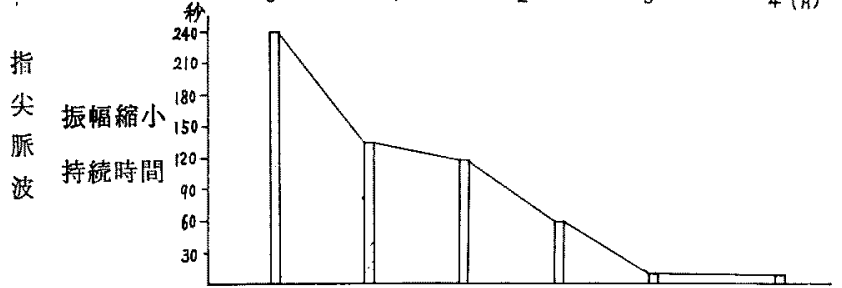
すなわち單純型受咽腔炎（仮称）と自律神経不 安定型戌咽腔炎（仮称）上に分類されるのを認 めた。

更に自律神経不安定型黡咽腔炎の患者 25 名 について，治瘾過侱々自律神経症状の消長並び 飞指尖血管運動反射の変動を観察し，鼻咽腔炎 を局所治療するのみで，随伴自律神経症状の軽

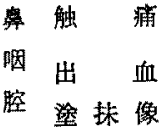

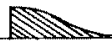
減と血管運動反射回復時間の正常化とる得た。 ここで注目に值するのは，局所の炎症が消退し た後る自律神程不安定状龍山続きとの鎮静によ り長期間の治療を要したことである．従つて自

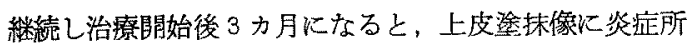
見の消失を認め，自律神経症状は便秘のみを残して，他 の症状は鎮静した。.このとき振幅縮小持続時間は 15 秒であり，正常の血管運動反射を得た。

\section{V. 総括並びに考按}

鼻咽腔炎の病態を詳細炕観察するとき，自律神経系の 関連性をどうしても看過することはできない，徒つて著 者は機能的な立場から鼻咽腔炎を解明 2.よ5と試み， pneumatic strain gauge PLG 使用により指尖の容積 变化を容器内流体の容積変化として記録し，血管運動反 射を中心洎律神経支配下にある末梢血行動態を観察し た。

まず予備実験を行い，正常者の舅咽腔刺湤による指尖 血管運動反射を測定した，その結果，正常者の悬咽腔刺 激による指尖血管運動反射の回復時間は，普通の刺激反 射や冷水による反射と比較しやや長い程度で，15 秒前 後であることを知つた．本実験ではこれを基準とし，血 管運動反射か 30 秒以下を正常々定めた。そして番咽腔 粘膜上皮塗抹標本検查火上り鼻咽腔炎と猃断された患者 50 名の初彭時に㧍ける血管運動反射を測定した結果， その多数煌管運動反射の異常光進をみた。すなるち 30 秒以下が 17 名, 30 秒以上が 33 名であつた。 ここで 鼠咽院炎に随伴している荿器別自律神経症状と血管運動 反射との関係を検討してみると，血管運動反射 30 秒以 下つまり正常血管運動反射の鼻咽腔炎患者に伴つている 自律神経症状は 3 症状以下であり，30 秒以上に血管運 動反射が異常充取している奥咽腔炎患者の自律神経症状 は 3 症状から7症状に及んでいた，換言すると，自律神
律神経不安定型舅咽腔炎の治療にあたつては，単に局所 のみの炎症消退を得たことで满足せず，随伴自律神経症 状をよく観察しながら治療する必要がある。

つで，血管運動反射の変動より鼻咽腔焱の治疮過程 を分類してみると，治癒例を大体 3 型に分けることがで きた．すなわち，血管運動反射回復時間の正常化が，単 純にしかも比較的短期間の浩㙩により得られる I 型及び 反射回復時間の短縮は漸滅的であるが，比較的長期間の 治療を要した $\mathbb{1}$ 型と，反射回復侍間が正常值に達するま で一進一退の経過を辿り，しかも長期治療を要した田型 に分類した，な怙，自律神絟不安定型鼻咽腔炎の治瘾に 要した治療期閒は，1 カ月〜4 カ月の例が多く，中には 12 力月も要した症例もある。

以上の観察をもとにして，學咽腔炎と自律神経系との 関係について中枢調整機序等の問題を含めて考察してみ たい.

鼻咽腔炎患者の鼻咽腔刺激に上る指尖血管運動反射を 測定したところ，反応時間の正常なるのと延長するるの があることを認めた，そこで鼻咽腔炎患者の指尖血管運 動反射が異常に立進したことに視点を当てて，その意味 するものを考察してみた。

PLG に上る末梢血行状態の镜察怯，指尖 cup 内下 含まれる諸血管、すなわち small artery, arteriole, meta arteriole, precapillary sphincter, true capillary, venule, small vein, arterio venous shunt 等の volume change の代数和をみるものである、こ のらち毛細血管の神経支配については古くから論議され ているが20)21)未だに不確かである。しかし small ar- 
tery, arteriole, meta arteriole, precapillary sphincter が自律神経系の支配下にあることは確かなこととし て知られている、このよらに自律神緼系の支配下にある 血管運動反射の買郜直進已いら現象は，いかなる機序に よりひき起こされるのであろうか，この疑間を追求する ことによつて，舅咽腔の保持方特殊機構が多少とる解 明されるものと考えられる。

以下十分な回答を得たとはいえないが，諸家の研究を 参昭しなが考察してみたい.

鼻咽腔刺激が血管連動反射を誘発する伝導路のうら， 主要な役割をなしているのは血管運動中枢であるら，從 つて血管連動反射の異常直進という現象る究明するため には，どうしてる血管連動中枢調整機序の問題に触れる 必要がある．この中枢としてまず考々られるのは脊䯣 である. Folkow ${ }^{10)}$ (種々の求心性 impuls が春䯣を 経て血管収綰性線維の形成する遠心性連鎖を巡り，宜䯣 邛管運動反射をひき起こすと述べ，更に延䯙にる血管運 動中枢があり，血管取維線維の繁彋を維持すると共似絶 え間なく barochemoreceptor からの impuls によつ て楥和されているという，又 Uvnäs ${ }^{26)}$ は延䯣尾部に pressor area とdepressor area とが局在し，血管緊張 あるいは血管緊張の㧕制関与していると述べている。 一方血管㹡張反応については，Bronk 4)5) の卓越した動 物実験があり，hypothalamus 前部の温熱放散中枢が

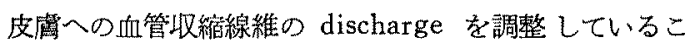
とを証明した，更に Uvnäs ${ }^{25)}$ の見解を採用すれば，

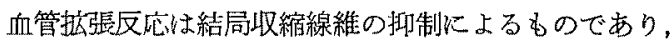
motor cortex $\rightarrow$ hypothalamus $\rightarrow$ medulla $\rightarrow$ spinal medulla $\rightarrow$ sympathetic nerve の経路を交感性抾張線維が 走ると考劣られる.

これら緒説を綜合檢討してみると，血管収縮線維の緊 張あるいは緊張抑制に主要な役割を演じているのは延郘邀 及び hypothalamusであり，末梢との密接な関連のも とに生体に加えられた刺激に対処して，全身血管を調整 していることになる，従つて粤咽腔刺激により起つた血 管運動反射の異常克進怔，血管収維の晎常持続を意味す るものであるから，血管運動中枢を含めた神経性調整機 能の破綎に上り起つた現象であると解釈される。換言す

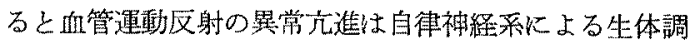
整機能の不調を租管調整の面から証明するものであると 考えられる。

著者は上述の推論を裏付ける意味で，Siebeck によ る葴器別自律神経症状の分類より10症状を選んで，渔
咽腔费者がどの程度に自律神経泟状を有しているか調 ベてみたのである、すなから，(1) 湿疹にかかり易い， (2) 冷感又心熱感，(3) 分汹異常，(4) 徐脈瀕脈不安定 (5) 心悸艺進，(3) 眩鼠，(7) 偏䫒痛，(8) 血王動摇，(9) 便 秘，(10)下痢の10症状はいずれも生体調整㙨能の不調を 示するのといえる。たとば血管収維神経緊張に傾いて いると，僅かな與奮で心臓収縮の促進，手足の冷感，胃 腸運動の不調による便敌，下㿇傾向をきたす結果とな る. かくして症候学的な面から悬咽腔炎を観察し，これ に血管連動反射の誘発実験を対比することにより，血管 運動反射の異常九進が生体調整機能の不調の粸現とみら れる自律神経症状と密接な関俰にあることを知つた，す なわら，鬼咽腔炎に随伴する自律神経症状が少い患者の 血管運動反射怔常であり，自律神経症状の多い患者の 血管連動反射は異常に九進していた。しかも，鼻咽空炎

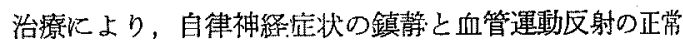
化とが平行して推移することを観察した，従つて，血管 運動反射の異常立進は自律神経系による生体調整機能の 不調を示するのに違いないという推論の誤りでないこと

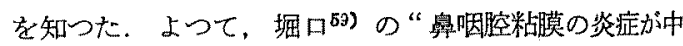
枢を含めて自律神経系に持続的刺激を与えるに違いな い”という見解を実験的に立証する端緒を把握し得たも

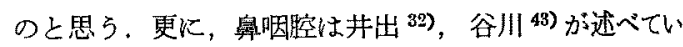
るょうに，塺埃，細菌の附着し易い部位であり，様々 な刺激に曝されているという部位的特徵に加え, chemoreceptor として，頸動脈洞神経の血管運動中枢に対 する優位性に関する Heymans ${ }^{19)}$ の学説を考慮する と，自律神経系に対する鼻咽腔の意義はいよいよ深いる のになると考える次第である.

\section{VI. 結 語}

鼻咽腔炎と自律神縕系との相互関係を把握しようと し，種々なる检查規準によつて舆咽腔炎と診断された患 者について，pneumatic strain gauge PLG 使用によ り，奥朋空炎並びに随伴自律神経症状の消長と指尖血管 運動反射の変動を臨床繦過と共に観察し次の結諭を得 た.

（1）鼻咽腔炎心，自律神絽不安定状態学随体与る自 律神経不安定型莮咽腔炎とこれを随伴しない単純型鼻咽 腔炎とに分類される。

（2）後者すなわち単純型楀㸶腔炎の指尖血管運動反 射は正常であり，前者すなわち自律神経不安定型磨咽膑 炎の指尖血管運動反射错常に九進する。

（3）率咽唉腔炎の消長と 自律神経不安定状態並びK 
指尖血管運動反射は，互に平行関係を保つて推移する。

（4）指尖血管遣動反射の変動より鼻咽喉腔の治癒過

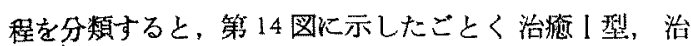

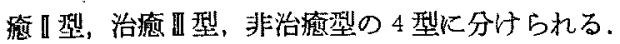

（5）與咽腔炎治療により，自律神繰不安定状熊の鎮 静と指尖血管運動反射の正常化とが得られる。

\section{然文献}

1) Bachrach, W.H.: Multiple simultaneous recording of gastrointestinal functions. Statham Lab. Instrument notes 21 ; 1952.

2) Bergmann, G.V. Die vegetativ Stigmatisierten und die Reaktion nach Reid-Hunt. Zbl. Klin. Med. 108, 100, 1928.

3) Brodie, T.G.: The gaseous metabolism of the kidney. J. Physiol. 32, 18, $1905 . \quad$ 4) Bronk, D.W. The activity of the cardiac sympathetic centers. Am. J. Physiol. 117, 237, $1936 . \quad$ 5) Bronk, D.W.: Excitability cycle of the hypothalamus sympathetic neuron system. Am. J. Physiol. 135, 504, 1942 . 6) Burch, G.E.: A new sensitive portable plethysmograph. Am. Heart. J. 33, 48, 1947. 7) Cannon, W.B.: Studies on the conditions of activity in endocrine organs. Am. J. Physiol. 96, 392, 1931.

8) Cannon, W.B.: Studies on the conditions of activity in endocrine organs. Am. J. Physiol. 104, 557, 1933. 9) Dale, H.H.: The chemical transmitter of vagus effects to the stomach. J. Physiol. 81, 320, 1934. 10) Folkoze, B.: Nervous control of the blood vessels. Physiol. Review. 35, 629, 1955. 11) Folkow, B.: The effect of the sympathetic vasoconstrictor fibres on the distribution of capillary blood flow in the intestine. Acta. Physiol. Scand. 61, 458, $1964 . \quad$ 12) Gaskell, P.: The significance of the "after-drop" in venous occlusion plethysmography. J. Physiol. 121, 627, 1956. 13) Gaskell, P.: The effect of intra-arterial atropine infusions on the blood flow through the human hand and forearm. J. Physiol. 131, 639, 1956. 14) Gotetz, R.H.: The rate and control of the blood flow through the skin of the lower extremities. Am. Heart. J. 31, 146, 1946.

Grant, R.T.: An explanation for the heightened vascular reactivity of the denervated rabbit's ear. J. Physiol. 121, 603, 1953. 16) Hertzman, A.B.:
Selective vascular reaction patterns in the nasal septum and skin of the extremities and head. Am. J. Physiol. 127, 671, 1939. 17) Hertzman, A.B.: Application of photoelectric plethysmography in peripheral vascular disease. Am. J. Physiol. 20, 750, 1940. 18) Hertzman, A.B.: The absence of vasoconstrictor reflexes in the head circulation. effects of cold. Am. J. Phyysiol. 136, 692, 1942. 19) Heymans, C: Survival and revival of nervous tissues after arrest of circulation physiol. Rev. 30, 375, 1950. 20) Hooker, D.R.: The functional activity of the capillaries. Am. J. Physiol. 54, 30, 1920. 21) Krogh, A.: Studies on the capillarimotor mechan sim. J. Physiol. 53, 418, 1920. 22) Langley, J.N.: The automomic nervous system. Cambridge, W. Heffer and Sons Ltd. 1921. 23) Merrillees, N.C.R.: Some observation on the fine structure and metabcilic activity of normal and glycerinated ventricular muscle of toad. J. Cell. Biol. 22, 533, 1964. 24) Siebeck, R.: Mohr Handb, d, inn, Med. III. Aufl. 1939. 25) Uvnäs, B.: Sympathetic vasodilator outflow. Physiol. Rev. 34, 608, 1954. 26) Uvnäs, B.: Postulated vasodilator in the medulla oblongata. Am. J. Physiol. 176, 68, 1954. 27) Winsor, T.: Clinical plethysmography. Angiology. 4, 149, 1953. 28) Winsor, T.: Peripheral vascular diseases. Charles $C$, Thomas publishing Co. 1959. 29) 池上芳男：プレチスモグラフ法 の比較的研究 呼吸之循環，6:59，1958（昭 33）. 30) 石川浩一：末梢血管の新しい検查法医学のあゆ2，25:

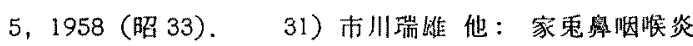
の䟝離細胞学的並びに病理学的研究。日耳鼻, 67:730, 1964（昭 39）。 32）井出靖头: 䟝離細胞像上り又

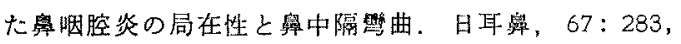
1964（昭 39）。33）内落耕二。可滑朌の自律神経支 配，神経釉末 医学のあゆみ。 54:83，1965（昭 40).

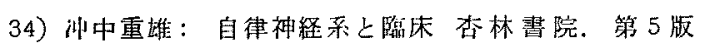
1958（昭 33）. 35) 加膦秀维: 反射光䉓䉓式 Ple-

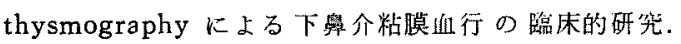
日耳鼠，68:305，1965（昭 40). 36) 北博正他: プレキスモグラフイについて，医器临、31:6, 1961

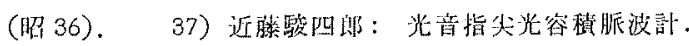

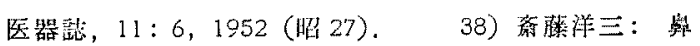




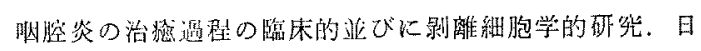

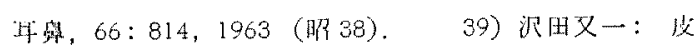

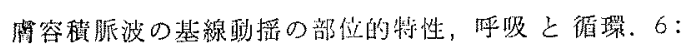

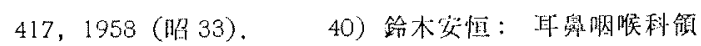
城に怙けるレーリ一氏琴象。日耳異，66：1473，1963

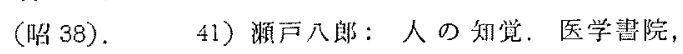

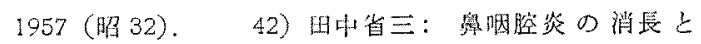
楾維絭溶解现象儿阅与研究。日耳鬼，68：675，1965

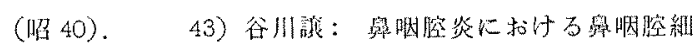

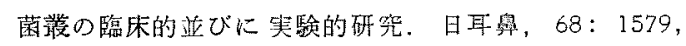

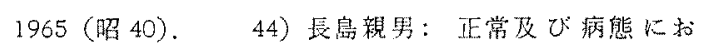
ける血管運動性に関する研究。日外会誌, 57：571， 1956 (炤 31)，45）展島長節：人体伹管の种経让 調整，東京大等出收会，1957（眧 32）。 46) 水瀨邦

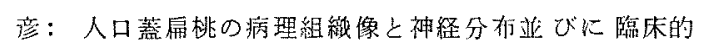

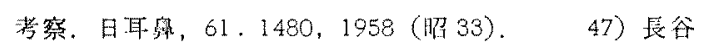

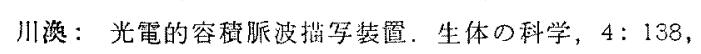
$1952($ 昭 27)。 48) 圽江沙: photo-transistor t応 用した受用光電式 plethysmograph の試作之䁷中隔粘 膜の血管応用。日耳舅，64：284，1961（昭 36）。49）

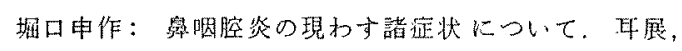
$63: 1480,1960$ (昭 35) 50) 堀口申作: 頭痛, 房 凝り之耳鼠咽喉科．治療，42：866，1960（昭 35).

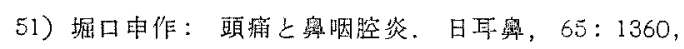

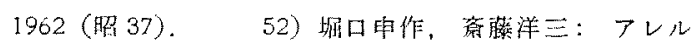

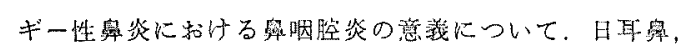
$65 ： 1368,1962$ (昭 37). 53) 堀口电作, 大久保仁:

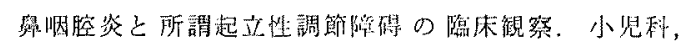
3:10，1962（昭 37). 54) 堋口申作, 藤森克男:

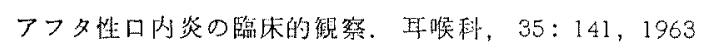

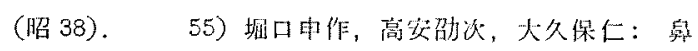

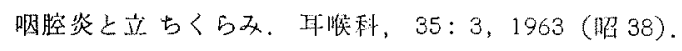

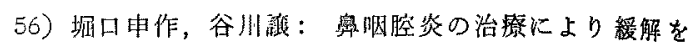

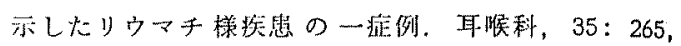

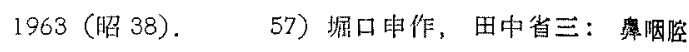
资とリウマヂ 日耳聯，68：221，1964（昭 39）。 58)

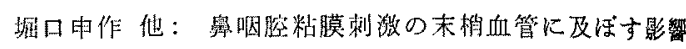
に関与名砳㚾（家禹耳介プレチスモグラによる観察）。

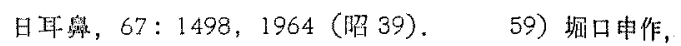

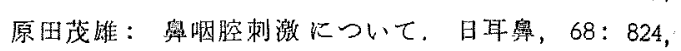
1965 (昭 40)，60）宮部整：成人口䒺粘膜に和ける 神経分布について。 日耳舅，63：1480，1960（昭35).

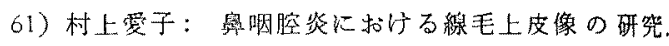

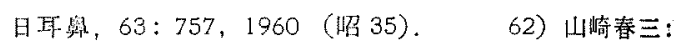

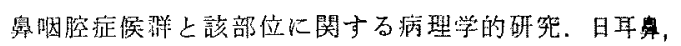

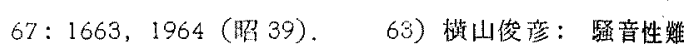
聴に関する吥然（第3報）騒音下従業員の自律神経並び に末梢循環機能状態力钼察。日耳學，66:675，1963 (昭 38).64）山口裕： ストレインダージ方式によ る指尖のブレチスモグラフに関する研究，执茶の水医 尌, 7:2245, 1959 (昭 34).

糊を䅂るにあたり，䅂始御留第なる御指導と御校 閲を賜つた恩師堀口申作教授，内科学島本多喜雄教

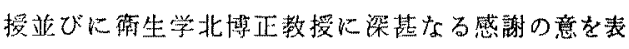

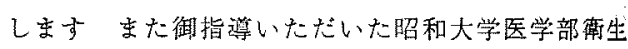
学山口裕助教授に梁謝いたします

な扣本論文の要旨は，炤和 41 年第67回日本耳奥

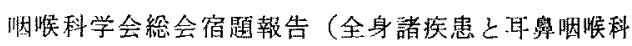

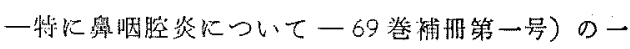
部上し，また昭和40年第 421 回日本耳舅咽喉科学

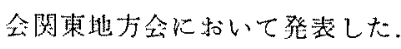

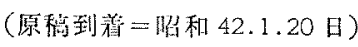

